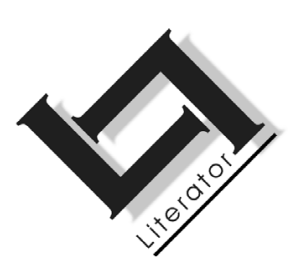

\title{
Authorial intention and agency in Luke's Acts
}

\author{
E. Mkhatshwa \\ Department of English \\ University of Zululand \\ KWADLANGEZWA \\ E-mail: emkhatsh@pan.uzulu.ac.za
}

\section{Abstract \\ Authorial intention and agency in Luke's Acts}

This article affirms the presence of the intentional consciousness in texts which purport to depict reality or real events. Intentionality, in the context of this article, is not conceived as a pre-existing thought or idea, which precedes the text, but as something which inheres in the text and is produced in it. The Cartesian split between consciousness and being which the former conception enacts is here elided and authorial intention is seen as something which is reproduced in the processes of writing and interpretation. This distinction is significant because the main argument of this article is that authorial intention in texts that purport to depict real events and intervene in a particular socio-historical process for mobilisational purposes, leads to the production of a certain kind of text which deploys specific narrative strategies that consolidate its reading and rendering of events and reinforce narrative closures. These intentionally motivated closures are embedded in narrative strategies, which are seen as both necessary and imperative for the consolidation and legitimation of the message and to foreclose other readings. Very briefly, this article seeks to reinscribe the agency of the author in his/her intentional stance with regard to the text. It further shows how this agency is enacted within the world of the text.

\section{Opsomming}

\section{Outeursintensie en handelingsrol in Lukas se Handelinge}

Hierdie artikel bevestig die teenwoordigheid van intensionele bewussyn in tekste wat hulle ten doel stel om die werklikheid of 
werklike gebeure uit te beeld. In die konteks van hierdie artikel word intensionaliteit nie gesien as 'n reeds bestaande idee wat die teks voorafgaan nie, maar as iets wat in die teks gevestig is en wat in die teks tot stand kom. Die Cartesiaanse verdeling tussen bewussyn en syn wat deur die eersgenoemde siening vergestalt word, word hier nie erken nie, en outeursintensie word gesien as iets wat geproduseer en begryp word in die prosesse van skryf en interpretasie. Hierdie onderskeid is belangrik, aangesien die hoofargument in hierdie artikel is dat outeursintensie in tekste wat poog om die werklikheid of werklike gebeure uit te beeld en sodoende toetree tot 'n bepaalde sosiohistoriese proses vir doeleindes van mobilisasie, lei tot die produksie van 'n spesifieke tipe teks. In sodanige teks word spesifieke narratiewe strategieë ontplooi wat 'n bepaalde siening en weergawe van gebeure bevestig, waardeur die narratiewe uitkoms versterk word. Hierdie intensioneel gemotiveerde uitkomste is ingebed in narratiewe strategieë, wat as noodsaaklik en onontbeerlik beskou word vir die konsolidasie en legitimasie van 'n bepaalde boodskap asook vir die uitsluiting van ander lesings. Kortom, hierdie artikel wil die handelingsrol van die outeur binne sy/haar intensionele instelling in die teks herwaardeer. Die artikel toon ook aan hoe hierdie handelingsrol sigself binne die teks afspeel.

\section{Introduction}

Many have undertaken to draw up an account of the things that have been fulfilled among us, just as they were handed down to us by those who, from the first, were eye-witnesses and servants of the Word. Therefore, since I myself have carefully investigated everything from the beginning, it seemed good also to me to write an orderly account for you, most excellent Theophilus, so that you may know the certainty of the things you have been taught. (Luke 1:1-4.)

In my former book, Theophilus, I wrote about all that Jesus began to do and to teach until the day He was taken up to heaven, after giving instructions through the Holy Spirit to the apostles He had chosen. (Acts 1:1-2.)

The writer's assertion, "In my former book, Theophilus, I wrote about all that Jesus began to do and teach" attests to the view that the writer of both Acts and Luke is one and the same person addressing his writing to a specific individual, namely Theophilus. The Book of Acts, therefore, is a continuation of the former book, namely, Luke. 


\subsection{Using the Bible for this article in particuler}

The Holy Bible which I chose to analyse for the purposes of this article, and the Book of Acts uses clear and simple language. The construction of the sentences is not as complex as one sometimes would encounter in texts either originally written in English or as translations. This somewhat less complex sentence structure renders the narrative easily accessible even to the average reader of the English language. Thus the message of the Book of Acts is to a very large extent clear and unequivocal as intended by the author.

\subsection{Redactional criticism as a critical factor in reading and interpreting Acts}

In Luke 1:1-4, Luke's assertion that it seemed to him also worthwhile to write an orderly account for the most excellent Theophilus is germane to the issues raised by redactional criticism of the role authors/redactors played in the realisation of the fixed written product accessible to us now. The writing of an orderly account, I argue, indicates the author's activity in the sequencing of events as they happened in actual historical moments. Thus in Luke and Acts as narrative texts, the portrayal of sequence according to the model of cause and purpose is important. Royse (2001:239), in an essay entitled, Scribal tendencies in the transmission of the text of the New Testament, also affirms on the scribal tendencies in the transmission of the text of the New Testament. The following remarks by Downing (1997:161) in an essay entitled, Redaction criticism: Josephus's antiquities and the synoptic Gospels, are worth quoting at length:

That the writers of the synoptic Gospels were redactors is largely accepted. They were neither simply repeating, recording, or working from memory; but neither were they just inventing material. They were using extant traditions, written or oral or both; they were adapting, embellishing, reordering, and perhaps also sometimes but not always creating narrative and speech, and it seems possible to detect at least something of the distinctive message that each writer's finished work conveys and was meant to convey.

Downing's view above is supported by Biddle's assertion that "redactors stood within received traditions. They did not offer replacements; they preserved, reinterpreted, and actualised traditions that were authoritative to them." (Biddle, 2004:138.)

By definition, redaction criticism is the theory that different copyists and commentators of the biblical writing embellished and altered 
biblical texts to make them more miraculous, inspirational, and legitimate (Perrin, 1969). As such, it is argued, redactional criticism reduces the quality of the biblical record, casts strong doubts on its inspiration, and implies that the Bible is not trustworthy as a historical document. According to Perrin (1969:2), the prime requisite for redactional criticism is the ability to trace the form and content of material used or concerned by the author in some way to determine the nature and extent of his activity in collecting and creating, as well as in arranging, editing, and composing.

It is worth noting, therefore, that redactional criticism is concerned with the theological motivation of an author as revealed in the collection, arrangement, editing, and modification of traditional material and in the composition of new material or the creation of new forms within the traditions of early Christianity (Perrin quoted in Donahue, 2004:141). It is also worth noting that redactional critics are primarily interested in the final shape of the material and also postulate theological reasons for the literary activity of the final editors. Thus in analysing Acts the focus, among other things, would be on the theological motivation that prompted Luke to write the text which is realised as the final fixed product accessible to us.

With regard to the editor's role in the production of the final text, Donahue (2004:144) is of the view that in the absence of clear sources, it is problematic whether the paring off of editorial accretions can ever disclose a tradition. Thus it is argued that renewed interest in ancient rhetoric and the literary forms of antiquity will more accurately disclose the literary activity and social location of a given author. In assessing redactional criticism as a literary and historical method, therefore, it is noted that although dominant and fruitful, the method is not without problems (Donahue, 2004:143). A case in point is when there is no clear source that attests to the textual history of a given document as is the case with Acts. This, according to Donahue (2004:143), is problematic since it makes it very difficult to separate tradition from redaction. It is against this background, therefore, that in this article textual history is not in the foreground, but rather the fixed final written product accessible to us.

In this article, I take the position that Luke's writing of Acts is a communicative act with an overt indication of intention, an intention which the text then reproduces in the structure of the narrative and the strategies of consolidation employed. Childs (1994:218), in a subsection entitled, "The contemporary debate over Acts", argues that Acts reflects a tendentious ideology of its author who idealised the early history of the church. Barnett (2003:146), in a chapter 
entitled "The Acts of the apostles", argues that in answering the question about Luke's purposes in writing Acts we must look in a straightforward way at his finished product and ask what it is that we discover in the finished textual product. It needs to be reiterated therefore that in this article the question of origin of the material contained in the text (Acts) is not what stands in the foreground, but rather, the problem of its function. Thus, in the context of this article, by function is meant the persuasive power of a text for the addressee and its actual effect.

The following discussion, therefore, is premised on the fact that writing as is the case in Acts is a social activity which culminates in the production of a text which is not an autonomous presentation of information, but a "social tool" used to effect specific outcomes. Hence I will argue that the impetus for Luke's writing of Acts is a functional one. Given the fact that Luke is writing within the socially recognised conventions and expectations of his time, his writing of Acts cannot be seen as isolated from the social world of interaction. It is in this respect, therefore, that Luke's cognitive activities as a writer are to be seen as arising from a reflexive awareness of writing as a process which "takes account of the potential audiences for the finished textual products" (Saville-Troike, 1995:258).

\section{Luke's use of language in Acts}

Luke's text assumes a functional view of language as the medium through which meaning is realised whereby language is not separated from content or context. This is reminiscent of Webster's $(1990: 63)$ assertion that "language is never neutral or ideologically innocent but is designed to convey particular kinds of knowledge to achieve certain effects". Words in Luke's narrative are transparent and fulfil a referential function as opposed to assuming a playful signification where reference and meaning are continuously deferred as is the case with the use of language in modern/postmodernist texts (cf. Bar-Efrat, 1989:198). In Acts the referential use of language contributes to the characterisation of the protagonists in terms of what they say and do. As Tiede (1980:111) points out Luke's characterisation of the protagonists Peter and Paul "portrays their actions and words against the background of the accomplishment of inscrutable and incomprehensible divine purposes through means of even the most hostile and blind human agents".

Luke's mode of argumentation uses language as a vehicle in the transmission of the argument and is informed and legitimised by his strategic use of scriptural historical reminiscences in which historical 
events are interpreted to account for present occurrences. In his depiction of the role, plight and tragic consequences of the actions of the characters, Luke deploys a referential language to achieve the desired effects. In Luke's text language is used to determine the nature of the world of the narrative including that of the characters populating it. Hence all the meanings embodied in the narrative of Luke are dependent upon that linguistic design (cf. Bar-Efrat, 1989: 197). Thus Luke deploys the necessary linguistic resources with which to deal with the content of Acts all the while keeping in focus the message which he aspires to confirm and disseminate. I argue that in Acts the written language and writing serve as mediums and the linguistic features reflect some functional purpose in the writing. In Acts there obtains identifiable formal properties and a complete structure (that is, a beginning, middle and an end).

The narrative in Acts is characterised by two distinguishable forms, namely a primary and a secondary form. Both of these forms constitute an apostolic quest mediated by the hero's act of agency. In the primary form the hero is depicted as undertaking a metaphorical journey which culminates in a manifest destiny whilst in the secondary form, through the hero's agency, the message of the gospel gets disseminated as occasioned by divine will. In Luke's text the plot of the narrative is made up of scenes that are arranged as a chain and develops from an initial situation, the Pentecost, that contains the enabling means upon which the activities of the characters depend. The plot in Acts not only serves to organise events, but also imbues the events in the narrative with significance which arouses the reader's interest and emotional involvement in what is being narrated (cf. Bar-Efrat, 1989:93).

\section{Characterisation in Luke's Acts}

Luke's text has two identifiable central figures, Peter and Paul, who assume the role of heroes in pursuit of a specific quest that is discernible in the narrative. Again in Luke's text the views and values embodied in the narrative are expressed through the characters' speech and actions, their fate (more specifically in the case of Paul) and the general course of events. These characters Peter and Paul transmit the significance and values of the narrative to the reader since they constitute the focal point of interest (cf. Bar-Efrat, 1989:47; 197). Peter's heroic acts are manifested in the first part of Luke's narrative and are confined to an exclusive Jewish audience whilst Paul's heroic acts occupy the second and remaining part of the narrative and are targeted at a predominantly gentile audience. 
Each hero is assigned to communicate the redemptive message of the gospel to a specific audience thereby reaching out to an encompassing and inclusive community of would-be believers. In Acts Luke presents Peter and Paul as primary actors and appointed witnesses who expedite the message of messianic salvation to the ends of the earth. Peter and Paul are conceived of as exceptional individuals whose function as characters in Webster's (1990:90) terms "is to bestow an acceptable identity on human subjects". Luke depicts the protagonists Peter and Paul respectively in ways that characteristically position and call upon the reader to identify with these heroes and espouse their worldview. The reader's identification with the hero's worldview in which ideological assumptions are inherently embedded not only positions him/her but also constructs him/her after the hero's image. In classical realist texts (defined as that in which an authorial intention and authoritarian metalanguage judge and control all the other discourses in the text), as is the case with Acts, readers are invited to share the insights of central characters or the narrator so that the sense they make of the text as reading subjects is mirrored in the way characters make sense of the events they experience (cf. Webster, 1990:83). According to Webster this positioning of individuals as reading subjects is synonymous with Foucault's notion of interpellation, a concept derived from Althusser, which is the process of recognition and identification whereby individuals are hailed or addressed in ways which position them. So the text's forms of communication, codes and strategies in effect manipulate and restrict the reader's sense of freedom to interpret the text as he/she wants, thus denying him/her a recognition of different reading positions and the play of the sign in the text (cf. Webster, 1990:27). In Luke's text the reading subject is thus positioned and constructed in ways that guide him/her towards discerning the purpose or underlying intention of the writing.

Luke's Acts belongs to the group of biblical texts that address a directed goal, which may rightly be identified as its author's intention (cf. Thiselton, 1992:560). As Thiselton (1992:561) points out Acts "serves primarily as transmissive and communicative vehicle to express the thought of an author towards a given directness". It is apparent from what has been said thus far that Acts as a classical realist text locates the author as the focal point of literary production as he (the author) has the leeway to manipulate both the linguistic and literary devices to serve his purpose. Thus Acts can be conceived in Webster's (1990:91) terms as a "control system, in terms of narrative methods, character construction and positioning, and the arrangement of the various discourses present". What is mani- 
fested in Acts, as a historical narrative, is a sharp contrast to what is discernible in certain kinds of texts that displace the author and his intentionality. Notably displacing the author and his intentionality (in texts other than classical realist ones) consequently relegates the text's central figure or the hero. The relegation of the hero or his/her abolishment is in essence a negation of the notion of the presence and privileging of the author's consciousness in the text's narrative that is often realised only through the hero's act and agency. But in Acts the hero's presence and agency are affirmed.

Having said this, I want to focus the following part of the discussion on how Luke, through the act and agency of Peter the apostle, makes a case for the authority and legitimacy of Christianity in a situation fraught with hostility towards it.

\section{Continuity and rupture in Luke's Acts}

In justifying Christianity's authority and legitimacy Luke convincingly presents the new religion (Christianity) as having a relationship with Judaism from which it emerged. This relationship is both one of continuity and rupture. In the context of this study continuity refers, to mention but a few, to the Old Testament Scriptures about God's plan for man, the sending of a Messiah and the covenants. The concept of rupture refers to a new beginning based on the Spirit rather than the letter of the law. As Henry (1979:44) points out "the history of Christianity in the first and second centuries is in large measure the story of attempts to establish and explain the continuity between Israel and the Church (Jewish-Christianity)". It is ironical as Henry (1979:44) observes, that the Jewish Christians "had not been conscious of a decisive rupture with the Jewish past or even with the Jewish present. There was not for them as there was in the gentile mission need for a cultural translation of the gospel". Luke's point of view in respect of continuity and rupture is that the Jewish-Christian community (that is the messianic community) has as yet failed though it is depicted as "striving to survive as viable testimony to the possibility of achieving a practical blending of Judaism and Christianity" (cf. Henry, 1979:44). The tension that obtains within the messianic community is demonstrated by the controversy regarding issues such as circumcision, food, inclusion of Gentiles as authentic proponents of the messianic community and other debates about Jewish customs which were seen to be incompatible with the demands of the new faith or religion.

Similarly Kee (1983:6) notes that some Jewish-Christians "stressed continuity with Judaism especially in conformity to the ritual laws 
about food and circumcision". It is apparent that Luke portrays the Jewish-Christian community as emphasising either the moral or the ritual dimension of the Jewish law. Notably the situation confronting the Jewish-Christians is presented as an interregnum, that is, an intermediate phase between the old and the new, a moment when the old is not yet completely obliterated and the new is not yet fully born. In such a situation tension is inevitable. Again in Acts Luke portrays the Jews as in general having forfeited their distinct identity as God's elect people and that this has come about as a result of their obstinacy and hard-heartedness as ancient prophets had prophesied and predicted that they would continue to be (cf. Henry, 1979:45). It is against this background that in Acts Luke depicts Peter as rendering a messianic interpretation of the events which were unfolding at the time. A case in point is Peter's response to the bewilderment of the Jewish rulers and elders as regard the healing of a crippled man. It is in relation to this divine spectacle (and many other spectacles as well) that Peter declares Jesus as the central figure of the new covenant thus nullifying the Mosaic laws with their attendant prohibitions. Peter boldly proclaims:

Rulers and elders of the people! If we are being called to account today for an act of kindness shown to a cripple and are asked how he was healed, then know this, you all the people of Israel: It is by the name of Jesus Christ of Nazareth, whom you crucified but whom God raised from the dead, that this man stands before you healed. He is 'the stone you builders rejected, which has become the cornerstone'. (Acts 4:8-11.)

Luke conceives of the messianic interpretation as a method of explaining and maintaining continuity between the heritage of Israel and the Christian community. Luke's view of Jesus as the central figure of the new covenant is foregrounded by the new covenant's prophecy alluded to in Jeremiah's prophetic proclamation (Jer. 31) to the effect that,
31 'The time is coming', declares the Lord,
'When I will make a new covenant with the house of Israel and with the house of Judah.
${ }^{32}$ It will not be like the covenant I made with their forefathers when I took them by the hand to lead them out of Egypt, because they broke my covenant, though I was a husband to them', 
declares the Lord.

33 'This is the covenant I will make

with the house of Israel

after that time',

declares the Lord.

'I will put my law in their minds

and write it on their hearts.

I will be their God,

and they will be my people.'

Tiede (1980:104) correctly observes that Luke's Theo-centric narrative "belongs more in the Jewish scriptural tradition of contemplating the wonder of God's awesome yet intentionally gracious involvement with the people". Burkett (2002:268) also observes that Acts of the apostles might be better named Acts of the Holy Spirit, for the Spirit becomes the driving force in spreading the gospel and establishing churches as God himself drives and directs this work of establishing Christianity through the Holy Spirit. Luke's narrative, therefore, is to be conceived of as offering pastoral assurances of the continuity of the Christian faith which deriving its authenticity and legitimacy from authoritative tradition (the above quotation from Jeremiah is a case in point) is refined and integrated into an interpretation of the times. As a matter of fact, Jewish tradition is replete with God's promises to the elect people. This is in large measure alluded to in the pronouncement "[t]he promise is for you and your children and all who are far-off - for all whom the Lord God will call". Luke views this pronouncement as a sign of continuing divine intention to bestow the promises on Israel. But the reference "and all who are far off - for all whom the Lord God will call" is presented as a critique of an exclusivist and constitutive understanding of Israel's election. Again Tiede (1980:119) points out that Luke's narrative also "manifests the adaptability of living traditions ... through restaging of the speeches in Acts to parade a cast of authoritative spokesman for credibly familiar yet recognisably Lucan views".

I would, therefore, argue that Luke's act of adapting living traditions in his writing of the Book of Acts is characteristically purposive and tendentious as these traditions form the basis of his own particular views on the subject being explicated in the text. In Acts Luke's writing is to be conceived of as the expression of a subject which in Gabel and Wheeler's (1990:5) terms, "is not something out there but something in here ... It exists in the author's consciousness; it is a conception of what the author wishes to express". 
This point of view accounts for Luke's purposive stance towards the events narrated in his text. Luke is of the view that Christians discovered a new identity in the context of the covenant community. Consequently, espousing the new covenant outrightly relegates the Mosaic covenant to a position of insignificance. Put differently, the Mosaic covenant no longer holds any promise for the Jews for Christ has appropriated the role once executed by the letter of the law. With Jesus as the cornerstone "salvation is found in no one else for there is no other name under heaven given to men by which we must be saved" save his (Jesus') name. So in Luke's narrative Jesus is presented as the Messiah and as the fulfilment of Jewish prophetic expectations. Luke's point of view is that the Spirit rather than the letter of the law as enunciated in the Mosaic tradition is accorded the central role in expediting the emergence of the messianic community.

\section{Identity transformation in the nascent messianic community}

Acts demonstrates how the Church came to wrestle with the place of Gentiles in the fledgling messianic community, faced the problem of the relation between the Mosaic covenant of law and the gospel of grace in Christ Jesus and learned to adapt its presentation of the good news to new contexts (cf. Carson, 1984:131). Clearly Luke's depiction of the conversion of Cornelius, the first Gentile convert, accounts for the positive stance he adopts in respect of the inclusion of Gentiles into the messianic community. Cornelius's conversion is presented as a precursor of the conversion of Gentiles into the Christian faith and his conversion sets the scene for the subsequent establishment of an inclusive Christian community. Cornelius' conversion breaks the long-standing barrier between Jews and Gentiles occasioned by the Mosaic laws which had denied Gentiles access of fellowship with God's elect people. In making a case for the inclusion of Gentiles into the new covenant Luke strategically portrays Peter (who is in large measure a conservative) as drastically undergoing transformation that culminates in his adoption of a liberal stance in respect of impartiality towards putative Others. The acquisition of a new consciousness on the part of Peter prepares him to assume agency of the transformative process geared towards the inclusion of Gentiles in God's plan of salvation.

Affirming his acceptance of the rupture as occasioned and sanctioned by divine will, Peter declares to Cornelius "You are well aware that it is against our law for a Jew to associate with a Gentile or visit 
him. But God has shown me that I should not call any man impure and unclean." (Acts 10:28.) Luke's characterisation of Peter exemplified by the foregrounding of his (Peter's) conciliatory position is meant to shed light on the kind of attitude (certainly impartial) expected of adherents of the fledgling messianic community. Luke's view here is that God's intervention has significantly moulded the understanding of Peter with regard to how members of the new Christian community should relate to the putative Other. Hence he (Peter) is portrayed as showing positive responsiveness by way of assuming agency and thereby championing the divine cause that would culminate in the realisation of the envisioned inclusive messianic community. Luke's positive stance as regards the inclusion of the Gentiles, notwithstanding he views this inclusion as constituting the central offence and controversy especially to those who regard ritual practices such as circumcision as a distinctive sign of the Jews as God's elect people. The irony of the controversy as to whether non-Jewish Christians be circumcised or not is that it is advocated by the very same people who constitute the messianic community and their advocacy in this regard presupposes that they did not fully comprehend the consequences of the rupture. Hence their (the Jewish-Christians) position that "it is necessary to circumcise them, and to charge them to keep the law of Moses" (Acts 15:5). Be that as it may, Luke's dominant view is that the Gentiles are counted worthy of God's promises as enshrined in the new covenant.

Luke makes use of Peter as a mouthpiece to represent and propagate the view that Gentiles through faith in Jesus are within reach of God's promises as regards salvation. Luke is of the view that the demand by Jewish-Christians that Gentile Christians should observe Jewish ritual practices such as circumcision which had become the distinctive sign of the Jews as God's people is tantamount to asserting Jewish cultural values and superiority to the detriment of gentile culture. The Jewish Christians' act of asserting their cultural superiority is in Luke's view decisive because as against the spirit of the new covenant it advocates the assimilation of the Other (the Gentile Christian) into the cultural values of the Self (the Jew). Clearly the subtlety of the process of assimilation contributes profoundly to the denigration and subsequent relegation of the Other's cultural values and identity to a position of insignificance and oblivion. Notably, assimilation results in the deculturation of the Other and is a process that is at variance with the humanising dimensions of the gospel as it involves among other things cultural domination of the Other by the Self. Thus I argue that in Acts Luke writes not only from the salvational or redemptive perspective but also from the liberationist 
perspective which he (Luke) deploys strategically in the narrative to counteract the advancement of Jewish claims to continuity of an exclusive identity that sets them apart as God's elect people.

Luke's attitude in respect of Jewish-Christians' hold and attachment to the Mosaic covenant is one of disapprobation. Luke views the act of striving to observe the Mosaic laws to the letter as having been nullified and substituted by the gospel of grace which affords individuals salvation indiscriminately as enunciated in the new covenant. But as Tiede points out, the affirmation that Gentiles are to be included as Gentiles without having to undergo circumcision provides grounds for the charge of apostasy levelled against the messianists by other Jews (cf. Tiede, 1980:53). The charge of apostasy specifically directed at Peter is vividly expressed by the circumcised believers' criticism that Peter "went into the house of uncircumcised men and ate with them" (Acts 11:3). This charge on the part of the circumcised believers shows notable aspects of Jewish values and racial relations rooted in the Mosaic covenant. From Luke's point of view Peter's association with the Gentiles is typically symbolic of the envisioned identity characterised by inclusiveness and affirmation to be accorded all members of the messianic community irrespective of racial origin and affiliation. But from the point of view of the circumcised Jewish-Christians Peter is identified as a person who deserves the status of a deviant. Peter's association with the Gentiles who are pejoratively labelled "outsiders" is seen by the Jewish-Christians as discreditable conduct and consequently gives rise to his stigmatisation.

Luke depicts Peter as assuming a new role and status of a suffering mediator and as a consequence he endures the human tragedy of rejection and misunderstanding with dignity as he denounces outrightly the "legitimate order". This point of view is accounted for by the fact that in the process of this denunciation the agent's (Peter's) former identity is virtually destroyed and a totally new identity established (cf. Malina quoted in Neyrey, 1991:107). As a result of his (the agent Peter's) newly acquired identity he is presented as of now as characteristically averse to the categorisation and differentiation of human subjects on the basis of cultural practices, racial origin and affiliation. It is against this background that Luke strategically portrays Peter (a Jew by racial definition) as having been subjected to character reconstruction prior to his becoming an agent of identity transformation and an advocate of the core values of the messianic community. Having thus acquired a new identity Peter then enters into a new social relationship with the gentile Christians. Luke's view 
in McVann's terms is that God occasioned Peter's "crossing of a line that cannot be crossed again" and that "with that crossing he has assumed a new identity with rights and obligations". Consequently "a fundamental life boundary has been crossed and its mark on personal and communal experience is virtually indelible" (cf. McVann quoted in Neyrey, 1991:333). With the designation of a new identity Peter cannot sustain his old identity. Clearly it is on the basis of his newly acquired identity that Peter is now invested with the right to speak in the name of core values that bestow upon the messianic community its distinctive character and identity.

\section{Inclusiveness in the messianic community}

Luke negatively portrays a Jewish community obsessed with boundaries of racial/social identity intent on the discrimination of the putative Others (cf. Malina quoted in Neyrey, 1991:113). Through the agency of Peter Luke challenges the dominant system of Jewish purity as informed by the Mosaic covenant or tradition. So in Acts Luke celebrates diversity in its manifestation of both divine will and triumph over and against human will. It is worth remarking therefore that Peter as portrayed by Luke is subjected by God's design to identity transformation and is in consequence equipped to meet the inevitable challenges of being an agent in this regard. The event of identity transformation and deliverance from prejudice against the Gentiles is an important marker not only for the character of Peter but also for the character of the emergent community of believers. Luke presents Peter's subjection to the riddance of prejudice as occasioned and precipitated by the vision, in which the Lord exhorted him saying, "[d]o not call anything impure that God has made clean" (Acts 11:9). Luke's view is that in terms of the new covenant as enunciated by the gospel of grace, the Gentiles are worthy of God's salvation. Peter's question, "So if God gave them the same gift as he gave us, who believed in the Lord Jesus Christ who was I to think that I could oppose God?" (Acts 11:17), is meant to give legitimacy and authority to the present impartial stance he advocates towards Gentiles. Therefore Luke's characterisation of and reconstitution of the character of Peter (who embodies and disseminates the core values of the messianic community) is reflective of his (Luke's) positive stance as regards the inclusion of Gentiles in God's plan of salvation.

I have thus far endeavoured to underscore the fact that in Acts Luke adopts a salvational or redemptive perspective that accounts for the activities of the apostles in propagating the gospel. The strategic 
value of the salvational perspective lies in its enabling potential, as its espousal by the apostles confers on them the requisite power to execute the mission entrusted upon them. No sooner had the apostles received "power from on high" than they assert in no uncertain terms that "salvation is found in no one else, for there is no other name under heaven given to men by which we must be saved" (Acts $4: 12$ ). Luke strategically begins the Book of Acts by embarking on a historical reminiscence in respect of what God had promised. The events narrated in Acts are presented as having been prompted, sanctioned, ordained and purposed by divine will. This is attested to by the prophetic citation:

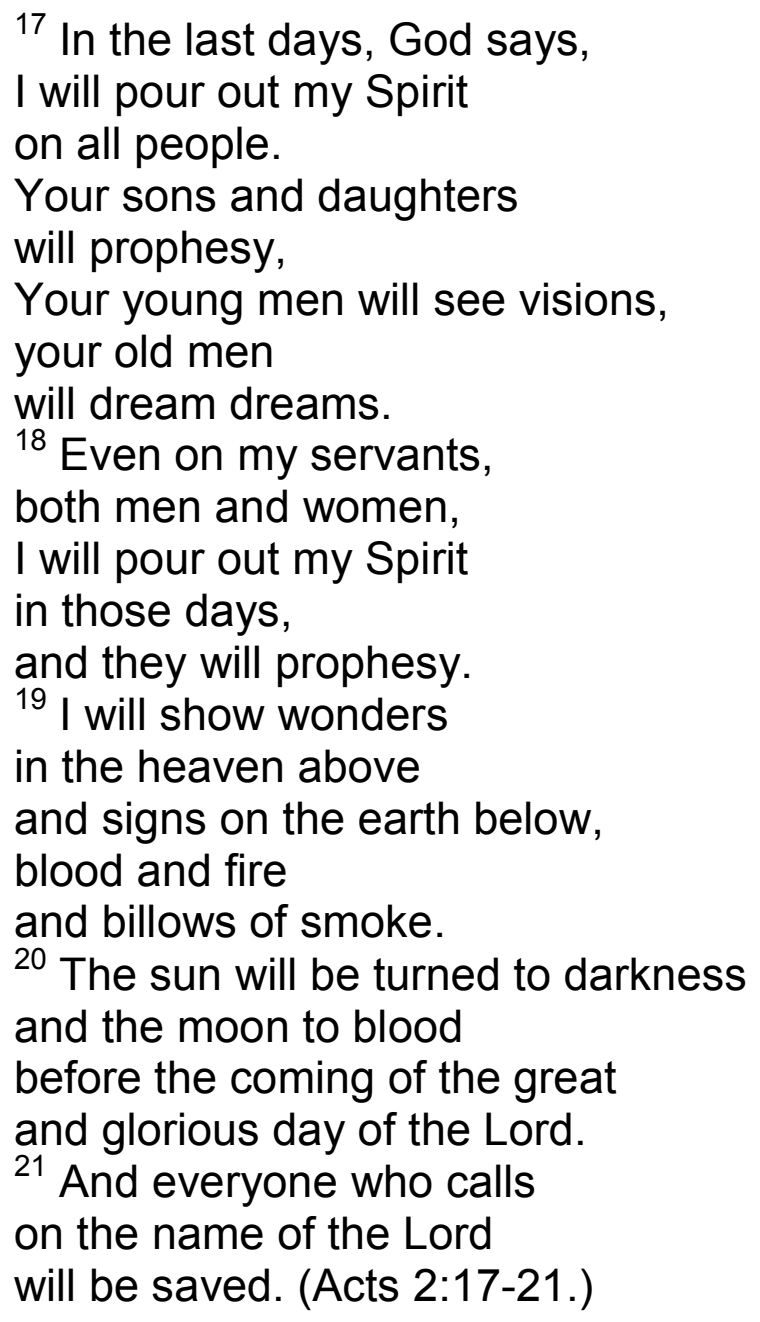

It is evident from the above citation that God's bestowal of divine power would as a future event be executed indiscriminately. This indiscriminate bestowal of divine power I would argue signals the coming into being of an inclusive community of believers whose distinct character and identity is derived from their identification with and submission to God's mission. God's pronouncement "I will pour out my Spirit on all people" is validated by the events at Pentecost where the believers had gathered for purposes of worshipping and 
subsequently received the Holy Spirit that had been promised "from on high". Thus bestowal of the Holy Spirit is a fulfilment of the promise, "I am going to send you what my Father has promised, but stay in the city until you have been clothed with power from on high", Jesus had made earlier to the disciples. Jesus' reassuring pronouncement "I am going to send you what my Father has promised" (Luke 24:49) is a cogent attestation to the fact that God has initiated and will accomplish (through the disciples) the mission $\mathrm{He}$ has entrusted upon them. Thus it is by design that the disciples should "stay in the city" until their empowerment for the impending mission has been effected.

It needs mentioning, though, that bestowal of the Holy Spirit on the disciples does not impact on their human dignity. They still remain ordinary human subjects who are endowed with all human qualities. Hence they are not immune to socio-political realities with all attendant constraints. The point I am trying to make here is that as ordinary human subjects the apostles are still subjected to besetting straits and all forms of human failure that one may think of. But since the mission in which they are involved is God's initiative, the power from on high with which they are clothed enables them to transcend their human limitations and thus emerge as victors in all trying circumstances or situations.

For purposes of clarity and precision I shall examine specific incidents or events which I believe constitute the bedrock on which Luke's underlying arguments or assertions about divine Will and intervention in human activities are premised.

\section{Purposive human agency as sanctioned by divine Will}

Luke presents Pentecost as affording the apostles the requisite power, that is, the enabling power to do even the seemingly impossible: "when the day of Pentecost came, all of them were filled with the Holy Spirit and began to speak in other tongues as the Spirit enabled them" (Acts 2:1). The apostles' ability to "speak in other tongues" is not an innate quality but is occasioned by the enabling power of the Holy Spirit. The divine spectacles astounded those who had known the apostles as their contemporaries prior to Pentecost. Hence they ask: "Are not all these men who are speaking Galileans? Then how is it that each of us hears them in his own native language?" (Acts 2:7-8.) These questions show that the apostles' activities are not derived from their human potentialities, for these activities do not seem to belong to the humanly possible. The language barrier, which is a characteristic feature among people who have 
diverse linguistic orientations, does not obtain where the Holy Spirit reigns supreme.

Notably bestowal of the Holy Spirit upon the apostles affords them the opportunity not only to witness for Christ but also to heal those who could not be healed by ordinary human means. Peter's act of healing "a man crippled from birth" who by virtue of his unfortunate situation was then reduced to be a beggar, provides the first instance of miraculous healing by the apostles. The incident of this man's healing is presented as having been confirmed by some onlookers who "recognised him as the same man who used to sit begging at the temple" (Acts 3:10). The close proximity of the onlookers to the scene of the crippled man's healing brings them to recognising that they are witnessing a divine spectacle. The ensuing bewilderment on the part of the onlookers in Jameson's (1981:113) terms "marks them as spectators surprised by the supernatural act ... into which they are unwittingly drawn ... without ever having quite been aware of what was at stake in the first place".

In response to all the people who were astonished by this supernatural act Peter ventures to ask: "Men of Israel, why does this surprise you? Why do you stare at us as if by our own power or godliness we had made this man walk?" (Acts 3:12.) I would argue that Jesus' reassurance that they would be his "witnesses in Jerusalem, and in all Judea and Samaria, and to the ends of the earth" (Acts $1: 18$ ), served to allay the fears and doubts on the part of the apostles as regards their strength both to execute the mission entrusted upon them and to withstand the times that were bound to beset them. Peter's question "Why do you stare at us as if by our own power or godliness we had made this man walk?" is in effect a confirmation of the fact that the apostles conceived of themselves as mere functionaries acting on a mandatory commission. Thus the apostles' act and its attendant effects or outcomes can only be attributed to the divine mandatory commission. Hence "by faith in the name of Jesus, this man whom you see and know was made strong. It is Jesus' name and the faith that comes through him that has given complete healing to him, as you can all see." (Acts 3:16.)

The performance of the said divine spectacle by the apostles bewilders not only the ordinary onlookers but also causes a furore for the Sanhedrin, that is, the highest court of justice and the supreme council in Jerusalem with 71 members. On hearing what the apostles had done, the Sanhedrin unwittingly finds itself having to uncover the enigma behind the apostles' act of healing the crippled man. Hence they ask: "By what power or what name did you do this?" 
(Acts 4:10.) This question from the Sanhedrin inadvertently affords the apostles the opportunity to witness for Christ and thereby exalt his name. Jesus' exaltation is eminently evident in Peter's reply: "It is by the name of Jesus Christ of Nazareth, whom you crucified but whom God raised from the dead, that this man stands before you healed ... Salvation is found in no one else, for there is no other name under heaven given to men by which we must be saved." (Acts $4: 10,12$.)

Peter's assertion serves to foreground the apostles' act of healing the crippled man within the nascent Christian tradition of miraculous healing bequeathed by Jesus. By thus foregrounding their act of healing the crippled man, the apostles are in essence legitimating the Christian faith from which they derive the power to do the seemingly impossible, by establishing the continuity between this act and the miraculous interventions in human affairs which Christ had begun. Inevitably the apostles' many actions evoke opposition and resistance from those who would like to maintain the status quo as regards religious affiliation and practices and they (the apostles) are consequentially commanded "not to speak or teach at all in the name of Jesus" (Acts 4:18). In response to the attempt to silence them the apostles unequivocally declare their loyalty by stating quite emphatically that they "cannot help speaking about what they have seen and heard" (Acts 4:20). In so responding it is as though the apostles seem to confirm Alcoff and Potter's (1993:112-113) illuminating assertion that "speaking should always carry with it an accountability and responsibility for what an individual says. To whom we are accountable is a political/epistemological choice contestable, contingent, and ... constructed through the process of discursive action." So even though restraining straits inevitably besets the advancement of the gospel of Jesus Christ the necessity to speak and thus take discursive action within a contested terrain is affirmed. The restraints to which the apostles are subjected serve among other things to test the distinctive character of their Christian identity and thereby attest to the indomitability of Christ' mission as it prevails against all oppositional forces.

\section{Providence as an enabling means}

Mindful of their human limitations the apostles are without doubt to have recourse to Providence when confronted with times that are potentially dangerous and life threatening. The apostles' reliance on Providence is demonstrated by their beseeching prayer to God from whom the requisite enabling means to withstand tribulations can be 
acquired. The formidable command given by the Sanhedrin to the effect that the apostles should forgot their activity and "not speak or teach at all in the name of Jesus" is aimed at curbing the influence of the apostles. Instead of taking fright and succumbing to the imposition of the Sanhedrin the apostles full-heartedly opt to render the prayer: "Now, Lord, consider their threats and enable your servants to speak your word with great boldness. Stretch out your hand to heal and perform miraculous signs and wonders through the name of your holy servant Jesus." (Acts 4:29-30.) Clearly to the apostles fortitude is characteristic of apostleship. As a confirmation of divine intervention in their precarious situation the apostles' prayer is responded to forthwith: "after they prayed, the place where they were meeting was shaken. And they were filled with the Holy Spirit and spoke the word of God boldly." (Acts 4:31.)

It is evident, therefore, that the apostles' act of propagating the message of the gospel and its accompanying acts of healing are not fortuitous but occasioned by God's initiative and sustained through the bestowal of the Holy Spirit upon the apostles who serve as functionaries in God's mission. Notably the positive responsiveness of the apostles to the mission entrusted upon them plays a decisive role in the realisation of the desired outcomes. Given the centrality of divine presence in the activities of the apostles the apostles are to all intents and purposes destined to triumph in all hazardous circumstances as long as they are championing the cause of Jesus Christ. And Luke's narrative foregrounds this by foreclosing other possible interpretations by his selection of the material presented and the use of an authorial metalanguage which controls the entire narrative.

Apart from Peter the other major character in this narrative is Paul. To qualify for this role Paul who was not initially a disciple of Christ and was not present at the Pentecost had to undergo a character transformation depicted in an event as miraculous as the empowering received by the disciples at Pentecost. Peter's two stage "conversion" first by the Holy Spirit and later by the vision from God in which he is told to call nothing made by God unclean, is mimed in Paul's conversion in the bolt of lighting that blinds him and then later again the scales that fall off his eyes and the changing of his name. Character transformation of this sort has always been an important part of Judaic traditions from the time of Moses and within the context of the culture and that it served as an instrument of identity formation. After transformation comes a new role. And for Saul, who becomes Paul, God's initiative is also manifested in his calling: "This man is my chosen instrument to carry my name before the Gentiles 
and their kings and before the people of Israel. I will show him how much he must suffer for my name." (Acts 9:15-16.) So it is foregrounded that Paul should serve in the advancement of the Word and thereby incur the wrath of those who are opposed to the espousal of the new faith, namely, Christianity. Paul is destined to suffer as sanctioned by divine will. In other words the subsequent dire straits he encounters in the course of his preaching have a divine purpose.

I would, therefore, argue that making it known beforehand that would-be preachers of the Word would be victimised, forestalls despair that would normally ensue as a result of subjection to relatively unprecedented tribulation. Paul, just like all other human subjects, was potentially vulnerable to persecution and all forms of human predicament. Thus Luke presents the forestalling of despair, as accomplished by the Lord's giving of assurance that divine intervention is readily available to provide the requisite spiritual support that would in effect see Paul through all the precarious situations he was bound to come across and come to terms with. It is in this respect therefore that the Lord at the moment when divine support was not only a necessity, but a must, said to Paul: "Do not be afraid; keep on speaking, do not be silent. For I am with you, and no one is going to attack and harm you because I have many people in this city." (Acts 18:9-10.)

The Lord's preponderate pronouncement "I have many people in this city" is indicative of the fact that Paul's activities are informed by God's design and purpose to bring about salvation to all human subjects. It is evident from this pronouncement that Paul is conceived of as a mere functionary (and this is attested to by the pronouncement "This man is my chosen instrument to carry my name") expediting that advancement of the gospel to which he himself had been called. As Moessner (1989:299) points out: "Luke presents Paul as following in the footsteps of his master in his journey-calling to witness to the Kingdom of God in suffering and affliction as he is rejected by an intractable people." The success of God's project to bring salvation to all rests not only on his (God's) initiative but also on the positive responsiveness of the agents (with specific reference to Peter and Paul) to the divine calling. Thus for Luke the agency of Paul and his unswerving commitment are central to the fulfilment of Jesus' demands. From Luke's point of view, as already alluded to, Paul is seen as a mere "messenger, divinely sent in real historical time and concrete situations to carry out specific events resulting in specific consequences" (cf. Moessner, 1989:308). It can therefore 
be asserted that Luke writes the "story of Christianity" with distinctive theological themes employing characters who act as agents of divine will and imbuing their experiences and actions with a recognisable pattern in terms of Judaic traditions.

\section{The cost of discipleship}

Luke presents Paul as having fully understood the cost of his calling. This understanding is shown in his encouraging and exhortatory address to the disciples when he points out "we must go through many hardships to enter the kingdom of God" (Acts 14:22). Paul is depicted not only as exhorting others to "remain true to the faith" but also as being himself exemplary in this regard. Paul's foreknowledge of the potential tribulations that await him does not in any way distract him from pursuing the goals of the God-initiated enterprise, which is the propagation of the gospel. This is demonstrated in his resolute commitment to face hardships with humility and dignity. Luke depicts Paul's positive responsiveness to the divine enterprise as both informed and constituted by a sense of self-denial and a readiness to become a suffering servant. The sense of self-denial or self-sacrifice is manifested by Paul's unequivocal proclamation when he says:

And now, compelled by the Spirit, I am going to Jerusalem, not knowing what will happen to me there. I only know that in every city the Holy Spirit warns me that prison and hardships are facing me. However, I consider my life worth nothing to me, if only I may finish the race and complete the task the Lord Jesus has given me - the task of testifying to the gospel of God's grace. (Acts 20:22-24.)

It is evident from the above quotation that Luke presents Paul as an agent who embraces God's cause (the task of testifying to the gospel of grace) without circumspection. In spite of the Holy Spirit's disclosure about the hardships that are destined to befall him, Paul resolves not to circumvent his destiny as sanctioned by divine will. The Lord had declared: "This man is my chosen instrument to carry my name before the Gentiles and their kings and before the people of Israel. I will show him how much he must suffer for my name." (Acts 9:15-16.) Clearly Luke depicts Paul as a quester championing the Lord's cause and having it brought to its logical end. Luke's view in this regard is that the realisation (that is seeing the end in sight) of God's plan of salvation depends not only on God's initiative and concomitant sustained involvement in the said initiative but also on the agency of those (with specific reference to Paul) who have been 
chosen to be his (God's) instrument. Notably Luke portrays Paul's quest as a metaphorical journey (as designated by race) occasioned and sustained by providential power. Luke's point of view therefore is that Paul's characteristic fixation and committal stance to the task entrusted upon him is accounted for by his (Paul's) certitude of God's unfailing presence and guaranteed divine intervention when the opportune moment for such intervention arrives. Paul's divinely directed journeys as regard the propagation of God's messianic mission in the world to save an intractable people, are to be accounted for by the fact that he (Paul) became an apostle by divine appointment. In other words, Luke presents Paul's apostleship and the attendant suffering as divine occurrences. There is therefore a provident design and a providential purpose in the hands of God to bring about a redemptive rupture which encompasses all people and that this will be achieved through purposive human agency.

I would argue for the central role played by agency in the transmission of the gospel of grace. Luke presents the Lord's declared will and Paul's obligation with respect to it as the basis for divine covenants with human subjects. But divine covenants between God and humanity can only materialise once obedience and submission to sovereign will have been inculcated on the part of God's agents. This is clearly manifested in Luke's portrayal of Paul (and Peter as well) as someone who positively responded to the Lord's call. As a consequence of his positive responsiveness to the calling, Paul subsequently had vicarious authority devolved on him and also obligations in respect of expediting God's mission of salvation. The bestowal of vicarious authority on both Peter and Paul serves as a positive divine confirmation of the covenantal principle between God and humanity. This vicarious or divine authority devolved on the agents (Peter and Paul) gives both ideological and theological legitimacy to the agents' act of questioning the Jewish impulse to self-preservation against infiltration by uncircumcised Gentiles who had become Christians. Luke therefore depicts Peter and Paul as agents fostering a new consciousness on the part of the Jews who up until then had been under the illusion of being still a distinct and exclusive community destined to enjoy the privilege of being God's elect people. But, in contradistinction to the Jewish Christians' obsession with upholding the prevalent conviction as regards their supposedly distinct identity (as occasioned by the Mosaic law) Luke presents Peter and Paul as harbingers expediting the coming-into-being of a new dispensation (the messianic community), characterised by the extension of God's grace of salvation to all humanity. 


\section{Conclusion}

In Acts Luke's foregrounding of the agency of Peter and Paul in his narration of the events, his use of the authorial metalanguage which privileges a central voice, and his employment of narrative strategies which control and direct the narrative in purposive ways towards a target audience, restricts, if it does not totally forestall the free-play of signification, thereby imposing a closure in one's reading and interpretation of the text. Thus in Acts the authorial intention processed through Luke's presentation of the apostles' activities as occasioned and sustained by providential power, is presented to Theophilus as the legitimisation of God's plan of salvation for all humanity. It is apparent therefore that Luke's presentation of the narrated events is not done perfunctorily as his writing is not disinterested. Instead his (Luke's) presentation serves to represent and validate his understanding and interpretation of both historical and contemporary events as congruent with God's new plan of salvation and that this must filter down to Theophilus so that he may "know the certainty of the things" he had been taught. Thus it can be asserted emphatically that since Luke's writing is not disinterested but is oriented towards the realisation of particular goals, authorial intention cannot be elided in interpretation as it already inheres in the text.

\section{List of references}

ALCOFF, L. \& POTTER, E. 1993. Feminist epistemologies. London: Routledge. BAR-EFRAT, S. 1989. Narrative art in the Bible. Tel Aviv: Almond.

BARNETT, P. 2003. Is the New Testament reliable? Downers Grove: InterVarsity.

BIDDLE, M.E. 2004. Hebrew Bible redaction criticism. (In Hayes, J.H., ed. Methods of biblical interpretation. Nashville: Abingdon. p. 138.)

BURKETT, D. 2002. An introduction to the New Testament and the origins of Christianity. Cambridge: Cambridge University Press.

CARSON, D.A. 1984. Exegetical fallacies. Michigan: Baker.

CHILDS, B.S. 1994. The New Testament as canon: an introduction. Valley Forage: Trinity.

DONAHUE, J.R. 2004. New Testament redaction criticism. (In Hayes, J.H., ed. Methods of biblical interpretation. Nashville: Abingdon. p. 141-143.)

DOWNING, F.G. 1997. Redaction criticism: Josephus's antiquities and synoptic Gospels. (In Porter, S.E. \& Evans, C.A., eds. New Testament interpretation and methods. Sheffield: Sheffield Academic Press. p. 161.)

GABEL, J.B. \& WHEELER, C.B. 1990. The Bible as literature: an introduction. 2nd ed. Oxford: Oxford University Press.

HENRY, P. 1979. New directions in the New Testament. London: SCM.

JAMESON, F. 1981. The political unconscious: narrative as a socially symbolic act. Cambridge: Cornell University Press. 
KEE, H.C. 1983. Understanding the New Testament. New Jersey: Prentice-Hall. MOESSNER, D.P. 1989. Lord of the banquet: the literary and theological significance of the Lukan travel narrative. Minneapolis: Fortress.

NEYREY, J.H., ed, 1991. The social world of Luke-Acts. Cambridge: Hendrickson.

PERRIN, N. 1969. What is redaction criticism? Philadelphia: Fortress.

ROYSE, J.R. 2001. Scribal tendencies in the transmission of the text of the New Testament. (In Ehrman, B.D. \& Holmes, M.W., eds. The text of the New Testament in contemporary research: essays on the status quaestionis. Eugene: Wipf \& Stock. p. 239.)

SAVILLE-TROIKE, M. 1995. The ethnography of communication. Oxford: Blackwell.

THISELTON, A.C. 1992. New horizons in hermeneutics. Michigan: Zondervan. TIEDE, D.L. 1980. Prophecy and history in Luke-Acts. Philadelphia: Fortress. WEBSTER, R. 1990. Studying literary theory. London: Arnold.

\section{Key concepts:}

authorial intention

purposive human agency

redemptive rupture (providentia Dei)

referential language

\section{Kernbegrippe:}

doelgerigte menslike handeling

outeursbedoeling, -intensie

verlossende deurbraak (providentia Dei)

verwysingsraamwerk (taal) 